\title{
Pahan pakko
}

Ari Hirvonen \& Toomas Kotkas (toim.): Radikaali paha. Paha eurooppalaisessa perinteessä. Loki-Kirjat 2004.

Radikaalissa pahassa on kaksi pääosastoa. Ensimmäinen sisältää suomennoksen Immanuel Kantin tutkielmasta "Pahan ja hyvän periaatteiden rinnakkaisuudesta eli radikaalista pahasta ihmisluonnossa" sekä suomentaja Markku Lehtisen johdantoartikkelin. Tutkielma on ensimmäinen osa kirjoitussarjasta Die Religion innerhalb der Grenzen der blossen Vernunft vuodelta 1792 (tekstissä se on otsikoitu "järjen rajoiksi", sisällysluettelossa järjen valoksi).

Toinen osasto jakautuu kolmeen osaan. Ensimmäisen osan otsikkona on "Paha ja vapaus". Jussi Kotkavirta, Sami Santanen ja Tuomas Nevanlinna paneutuvat siinä suoraan Kantin radikaalin pahan problematiikkaan. Ari Hirvonen pohtii Kantin oikeusopin suhdetta Kolmannen valtakunnan "laillisiin" hirmutekoihin, ja Susanna Snell jatkaa totalitarismin käsittelyä siirtyen Kantista Hannah Arendtiin ja tämän tutkimukseen Adolf Eichmanista ja pahan banaalisuudesta. Toisessa osassa, "Pahan genealogia",
Hannu Sivenius ja Miika Luoto tarkastelevat Nietzschen tapaa ymmärtää hyvän ja pahan historiallinen synty, ja Toomas Kotkas pohtii rikoslain ja pahan suhdetta Foucault'n ajattelussa. Kolmannen osan, "Paha maailma", aloittaa Jari Kauppisen artikkeli Derridan tekemästä pahan dekonstruktiosta erityisesti yliopiston, uskonnon ja psykoanalyysin yhteydessä. Janne Porttikivi jatkaa tästä lacanilaiseen psykoanalyysiin, ja Juhani Lindell kirjoittaa Freudin ja Lacanin teorioista. Jarna Petman pohtii pahuuden retoriikkaa kansainvälisessä politiikassa, kansainvälisen oikeuden käytännöissä sekä terrorismin käsitteellistämisessä. Kirjan päättää Jari Kauppisen kokoama bibliografia "Kirjallisuutta pahasta”.

Artikkelien sijoittaminen on välillä yllättävää. Miksi Hirvosen ja Snellin totalitarismia käsittelevät artikkelit eivät kuulu "Pahaan maailmaan", ja miksi Derridaa ja psykoanalyysia käsittelevät artikkelit kuuluvat siihen? Sisäistäkin pahuutta käsitellään psykoanalyysin käsittein jo 
Kotkavirran artikkelissa. Sinänsä tällaisten säikeiden risteily sopii virittämään ajatuksia; ehkä painotuseroista ei kannata kiistellä.

Kirja on tulosta Helsingin yliopiston filosofian laitoksen Laki ja paha -tutkimushankkeesta. Hanke on näkynyt ulospäin myös "Pahan kasvoja" -kollokviossa, ja ainakin jo Nuori Voima -lehden Pahanumerossa (2/01) on ilmestynyt esitöitä.

Rajaan esittelyni Kantin keskeisiin moraalia ja pahaa koskeviin ajatuksiin. Sen jälkeen pitäydyn artikkeleissa, joissa paneudutaan nimenomaan Kantin filosofiseen ajatteluun, sekä tarkastelen lyhyemmin kahta Nietzscheä käsittelevää artikkelia. Näistä avautuu kaksi erilaista näkökulmaa etiikan kysymyksiin. Valintani eivät ole arvottavia.

\section{Pahan välttämättömyys Kantin ajattelussa}

Pahan ongelma on askarruttanut länsimaisia filosofeja antiikista alkaen. Kristinuskon aikana teologinen kysymys taas on, miksi kaikkivoipa Jumala sallii pahan. Kant katkaisi siteet teologiseen pahan selittelyyn, teodikeaan. Pahan ongelma jäi filosofiassakin taka-alalle ja siitä tuli lähinnä psykiatrian, sosiologian tai biologian asia. Kuten Jarna Petman huomauttaa, pahuus on viime aikoina palannut myös filosofiseen keskusteluun, varsinkin kantilaisin ja lacanilaisin painotuksin. Pahuuden retoriikkaa käytetään poliittisessa elämässä, sellaisena "pahuuden patologisena dialektiikkana”, jossa pahuus irrotetaan yhteyksistään ja dialogin mahdollisuudesta. Uusi filosofis-psykoanalyyttinen keskustelu toimii tällaista retoriikkaa vastaan. Tätä keskustelua kehitellään myös tässä kirjassa.

Kirjassa puhutaan "pahasta eurooppalaisessa perinteessä". Kantin ajattelusta juontuukin juuri eurooppalainen hyvän ja pahan jännite. Valistusaika loi järjen ja humanismin liiton, jonka piti viedä länsimainen ihminen - universaalisuuden lupauksin - pois siitä raakalaisuuden tilasta, jota pitivät yllä "alaikäinen" alistuminen uskomuksille ja ennakkoluuloille. Kantin tiivistämä ajatus valistuksesta ihmisen täysi-ikäisyytenä oli avaamassa tietoisen muutoksen ja edistyksen näköalaa.

Valistusta on arvosteltu yhteiskunnallista kehitystä ja ihmisen moraalista täydellistymistä koskevien ajatusten yksioikoisuudesta. Ajatus siitä, että valistunut järki tuottaisi humaanimman yhteiskunnan, ei ole kestänyt maailmansotien, 1900-luvun totalitarismien ja keskitysleirien todellisuutta. Moraalin ja hyvän elämän perusteiden pohtimista kalvaa kysymys siitä, kuinka näin käsittämätön paha ylimalkaan on mahdollista.

Immanuel Kant oli keskeinen valistusfilosofi, mutta hän ei oikaissut historiaa järjen voittokuluksi. Kantin ajattelu on rajankäyntiä: puhdas järki yltää tuohon, ei edemmäs, kokemustodellisuutta hahmottava teoreettinen järki puolestaan tähän, moraalista toimintaa ohjaava puhdas käytännöllinen järki omalle alueelleen ja esteettinen arvostelukyky omalleen. Kartoittaessaan järjen rajoja Kant pyrki estämään sekä rationalismin että empirismin ylilyönnit.

Kant märitellään modernin paha- 
keskustelun avaajaksi, koska hän siirtää sivuun teodikean ja tekee pahasta ihmisen omaa vapautta ja vastuuta koskevan kysymyksen. Tähän myös artikkelit keskittyvät; toimittajat toteavat kaikkien kirjoittajien olevan tavallaan "Kantin lapsia”, eikä pahalle sen vuoksi juuri omisteta "yhtäältä teologian ja toisaalta sosiaalibiologian" mukaista huomiota.

Mitä siis on se "radikaali paha", jota Kant pohtii tutkielmassaan ja jota artikkeleissa käsitellään? "Paha" on Kantille vapauden paradoksaalinen ulottuvuus. Kant kiistää puhtaan järjen mahdollisuuden luoda yksinään teoreettisia väittämiä empiirisestä todellisuudesta, mutta etiikan alueella ei hänen mukaansa mitään muuta olekaan kuin puhdas järki, johon tukeutua. Moraaliset periaatteet, tieto väärästä ja oikeasta toiminnasta, ovat myötäsyntyisiä. Moraali on myös autonomista, koska moraalisesti hyväksyttävän teon perusteena eivät ole sen seuraukset vaan moraalilain ehdoton noudattaminen. Moraalilaki ilmenee eri tilanteisiin sopivina toimintaohjeina, maksiimeina, joiden oikeellisuuden voi arvioida siitä, kelpaavatko ne yleispäteväksi laiksi. Maksiimeissa ilmenevä moraalilaki antaa toiminnalle moraalisen muodon.

Moraalin yleisenä perusteena Kant pitää luontaista tahtoa hyvään. Siihen päästään vain, jos moraalisiin näkökohtiin ei suhtauduta välineellisesti vaan päämääränä sinänsä. Puhdas järki merkitsee myös tahdon vapautta. Tässä vapauden valtakunnassa ihminen on siirtynyt pois ajan ja tilan, esineellisyyden ja syysuhteen maailmasta järjellä käsitettävään maailmaan.
Siinä maailmassa voi - loogisen ajattelun lisäksi - olla vain moraalisesti toimivana olentona. Kant olettaa puhtaan ajattelun aktin, jonka avulla vapauden valtakuntaan siirtyminen on mahdollista. Laille alistuminen on valinta, tahdon asia.

"Radikaali paha" ei tarkoita mahdollisimman pahaa vaan sitä, että voidakseen vapaasti valita hyvän on voitava valita myös paha. Moraalin ongelma on se, että moraali liittyy tekoihin ja toimintaan ja sen vuoksi myös luonnonvälttämättömyyteen. Siksi moraalin "äärettömyys", riippumattomuus, koskettaa aina äärellistä. Äärelliseen kuuluvat ihmisen luonnolliset pyyteet; ne eivät sinänsä ole pahoja, mutta vaikuttaessaan moraalisiin toimintaohjeisiin ne vetävät ihmistä pahaan. Pahan radikaalius - sen juuret ja juurimattomuus - kuvaa moraalin alueella ihmisen pääsemättömyyttä äärettömyyden ja äärellisyyden, vapauden ja luonnon ristiriidasta.

Kantin "radikaali paha" voidaan asettaa hänen valistunutta ihmistä kuvaavan autonomia- ja täysi-ikäisyysajatuksensa rinnalle. Samalla pahan radikaalius heittää varjonsa kaikkeen järjelliseen toiveikkuuteen. Valistuksen ajan virittämä toivo, joka romahti historian kulussa, ei ollut vailla pahoja aavistuksia syntymänsäkään hetkellä.

\section{Uutta keskustelua Kantin etiikasta}

Artikkelissaan ”Hyvän ja pahan lähteellä” Jussi Kotkavirta käsittelee myös muita Kantin kirjoituksia. Kantin "leikkimielinen" Genesis-tulkinta ei ole yllättävä, 
mutta osoittaa (tätä ei Kotkavirta korosta), että vaikka Kant irtautuu teodikeasta käsitteellisesti, hän on riippuvainen teodikean sisältämistä tarinoista heti ryhtyessään havainnollistamaan ajatuksiaan. Paratiisin vaistonvarainen elämä rikkoutui, kun järki alkoi ohjata tekemään vertailuja. Kielletyn hedelmän maistaminen johti uusiin, myös luonnottomiin nautintoihin. Halujen ristiriitaisuus herätti kysymyksen moraalisesti oikeasta ja ihmisen kyvystä "valita itselleen elämän kulku”. Tämä johti halujen säätelyyn ja taipumukseen hankkia "toisten kunnioitusta hyvällä käytöksellä” ja kätkemällä sen, mikä voisi aiheuttaa väheksyntää. Tästä seuraa "loputon kulttuurin laajennusten sarja”.

Tämä muistuttaa Rousseaun ajatusta kulttuurista tapojen turmelijana ja viittaa myös Nietzscheen, joka yhdisti moraalin synnyn teeskentelyyn, peittelyyn ja hämäykseen. Kotkavirta nostaa keskeiseksi käsitteeksi Kantin ajatuksen ihmisen "epäseurallisesta seurallisuudesta". Ihmisen pyrkimys muodostaa yhteiskunta on antagonismin läpitunkema: yhdistymisen tarpeeseen liittyy eristäytymisen pyrkimys, vastarinta. Vastarinta on samalla pyrkimystä oman aseman vahvistamiseen. Se saa ihmisen voittamaan laiskuutensa ja herättää hänen kunnian, vallan ja omistamisen himonsa. Tämä kuitenkin määrittelee vain moraalin "toisen puolen", ihmisen käyttäytymisen aistien ja kokemusten ohjaamana luonnonolentona. Järkiolentona ihminen voi nousta tällaisten vaikuttimien yläpuolelle ja tajuta moraaliset toimintaohjeet kategorisen impe- ratiivin pohjalta. Ihmisten pärjääminen maailmassa jää kuitenkin riippumaan siitä, että ehdottoman moraaliohjeen noudattamisesta syntyvä itsekunnioitus sekoitetaan onnistuneesta moraalisesta manipuloinnista koituvaan arvostukseen. Tämä sekaannus pitää Kantin mukaan yllä "ihmisten välistä kilpailua ja heidän kykyjensä kehitystä”. Kaksinaisuus kertoo myös liberalismin molemmista puolista: yhtäältä tähän kuuluu yksilön moraalisten valintojen vapaus ja riippumattomuus sekä niihin liittyvä vastuu ja toisaalta yksilöiden välinen kilpailu ja moraalinen manipulointi - eli "päämäärä itsessään” ja välineellisyys.

Richard Bernstein pitää ristiriitaisena Kantin ajatusta, että ihmiseen on toisaalta juurtunut universaali taipumus pahaan mutta että ihmistä silti voi pitää siitä vastuullisena. Kotkavirran mukaan ristiriitaa ei ole, koska Kantin ajatus pulmallisesta seurallisuudesta osoittaa ihmisen ristiriitaisuuden ja antaa samalla puitteet pyrkimykselle saada se moraaliseen hallintaan. Mutta onko asia sillä hyvä? Kantin ikään kuin annetaan päästää itse itsensä veräjästä. Liberalismin sisäisen ristiriidan kannalta Kantin ihmiskäsityskin näyttäytyy eri valossa. Hänen tekemänsä jyrkän jaon ihmiseen järkiolentona ja luonnonolentona voi nähdä liberalismin dilemman filosofisena antropologisointina ja samalla sen oikeuttamisena. Ristiriidan pysäyttäminen kahteen ylittämättömään horisonttiin ikuistaa tilanteen ja antaa pahalle sen radikaalisti modernin ajatusmuodon. Tämä paha on laajasti ottaen historiallisen ratkaisemattomuuden allegorisointi. 
Lacanilaisittain Kantin radikaali paha on se reaalinen, se kipupiste, joka tekee itsensä tiettäväksi mutta joka ei suostu sen enempää kuviteltavaksi kuin omaksuttavaksi symboliseen järjestykseen.

Kotkavirta viittaa freudilaiseen käsitykseen ihmisen psyyken ristiriitaisesta dynamiikasta, hyvän ja pahan samanaikaiseen läsnäoloon, ja siihen että niiden erilleen lohkomisella voi olla kohtalokkaita seurauksia. Kotkavirran mukaan psykoanalyysi pyrkii hyvän ja pahan sitomiseen ja pahan tietynlaiseen neutralointiin symbolisaation keinoin. Kantin suhde tähän on nähdäkseni kuitenkin kaksinkertaisesti ambivalentti. Toisaalta käytännöllisen järjen moraaliohjeet vetävät yksilöitä ja yhteiskuntia kohti eettisesti kestävämpää elämää, toisaalta järjellisen ja luonnollisen väliin jää ylittämätön kuilu ja ajattelun peruseleeksi siis lohkominen. Radikaali paha on tämän kuilun kuvausta moraalin termein. Sellaisena Kantin paha on radikaalisti ratkaisematonta, sitomatonta. Se vastustaa symbolisaatiota. Ehkä niin on aina, antropologisesti, mutta paradoksaalisesti Kant antaa sille myös käsitteellisen rakenteen, joka vaikuttaa ymmärtämisen esteenä. Kotkavirta huomauttaakin, ettei Kantin termein ole mahdollista käsittää tavallisten ihmisten pahuutta poikkeusoloissa. Sen sijaan hän tuo esiin Melanie Kleinin ja Christopher Bollasin ajatuksia "pahuuden psyykkisistä rakenteista".

Järjellisen ja luonnollisen välinen halkeama ei tarkoita jakoa, jota voi kuvata manikealaisena hyvän ja pahan ikuisena taisteluna. Sami Santanen korostaa tiiviissä artikkelissaan "Radikaali paha
- (epä)inhimillistä?”, että hyvän ja pahan taistelun sijasta Kant näkee niiden suhteen vapauden ja vastuun kysymyksenä. Näin se ei myöskään merkitse teodikean ajatusta pahasta hyvän puuttumisena. Loogisessa ristiriidassa myöntävä ja kieltävä predikaatti kumoavat toisensa, mutta reaalioppositiossa kaksi myöntävää predikaattia (kuten nouseminen ja vajoaminen) asettuvat vastakkain. Myös moraaliset valinnat ovat tällaisia. Sen vuoksi ei voi olla olemassa mitään moraalisia välimuotoja kuten empiirisessä todellisuudessa. Moraalilain ehdottomuus tekee tietoiseksi valitsemiskyvyn riippumattomuuden muista vaikuttimista. Niin radikaali paha kuin valitsemiskykyyn iskostunut "taipumus pahaan" ovat transsendentaalisia eli ne on omaksuttu valitsemiskyvyn periaatteiksi ajallisista ehdoista riippumatta. Asia menee tavattoman monimutkaiseksi, kun Kant toisaalta luonnehtii pahan taipumusta ja sitä lähenevää radikaalia pahaa satunnaisiksi verrattuna ihmisluonnon alkuperäiseen taipumukseen tehdä hyvää. Varsinaisen Kant-tutkimuksen kannalta Santasen eri teoreetikkoihin tukeutuva keskustelu tästä aiheesta on tärkeää, mutta nähdäkseni siinä on lopulta kysymys väistämättömästä ja hedelmättömästä käsitteellisestä horjunnasta, joka seuraa moraalisten toimintaohjeiden sijoittamisesta omaksi alueekseen hypostasoidun puhtaan järjen ja absoluuttisen vapauden piiriin. Käsitteellinen liikehdintä näin syntyvässä järjen ja luonnon välisessä kuilussa on väistämättä loputtomasti korjaavaa. Tämä korjailu ei johda dekonstruktioon, koska se ei kyseenalaista vastakohta- 
asetelmaa.

Kuten Tuomas Nevanlinna huomauttaa artikkelissaan "Radikaali ja diabolinen paha”, miksi-kysymyksiä moraalisen valinnan syistä ei voi esittää, koska se loukkaisi vapauden periaatetta. Tämä jättää kuitenkin auki kysymyksen, mikä valinnoissa on vapaata ja mikä ehdollista. Nevanlinna - joka pohtii näitä kysymyksiä sloveenifilosofien Slavoj Žižekin, Joan Copjecin ja Alenka Zupančičin avulla - määrittää valinnan vapautta lacanilaisella pakotetun valinnan käsitteellä. Tällaisen valinnan tekee esimerkillisesti Oidipus, joka subjektivoi, ottaa omakseen kohtalonsa. Oidipusta kohtaavien tapahtumien kohtalonomaisuus ei ollut hänen valittavissaan. Silti hän tässä vaihtoehdottomuudessa valitsee itsensä. En jää nyt pohtimaan sitä, että laittamalla tapahtumien paikalle diskurssin ja vaihtamalla etumerkin olemme varsin lähellä althusserilaista ideologian subjektia. Sen sijaan ihmettelen esimerkkiä fetisismistä, jossa korkokengän valitseminen halun perimmäiseksi objektiksi ja vaikuttimeksi määritellään samanlaiseksi pakotetuksi valinnaksi, jossa "subjekti edeltää kaikkia objektejaan". Se että emme voi sanoa minä päivänä satsaus tapahtui, vaan että se on ymmärrettävä tiedostamattoman tai kantilaisittain "mielenlaadun" tason tapahtumaksi, ei riitä tekemään siitä pakotettua valintaa tässä merkityksessä. Addiktioiden muodostuminen on ilmiöllinen ja psyykkinen tapahtuma. Tiedostamattomassa tapahtuva on "aina jo", mutta se on silti prosessi tihentymineen ja siirtymineen; moraalisen toimintaohjeen transsendentaalinen valinta on kerrallinen, ehdoton. Kantilaisittain voi tietenkin ajatella, että taipumuksena addiktio on moraalisen valinnan piirissä.

Nevanlinna esittää syyllisyyden yhdistävän Kantin ajattelua ja psykoanalyysia. Syyllisyys ei välttämättä synny siitä, että olisimme todella tehneet jotain väärää, vaan se ilmoittaa meille, ettemme vajavaisina olentoina koskaan kykene täysin toimimaan kategorisen imperatiivin tai yliminän vaatimusten mukaisesti. Samalla "huono omatunto" kertoo meille negatiivisesti toisin valitsemisen mahdollisuudesta.

Tämä näyttää kyseenalaistavan edellä esittämäni ajatuksen kantilaisesta lohkomisesta. Lohkominen viittaa ambivalenssin rikkovaan ja eheyttävää symbolisaatiota karttavaan hyviksi ja pahoiksi varattujen elementtien erottamiseen toisistaan ja pelaamiseen toisiaan vastaan. Tässä tapauksessa se näyttää tarkoittavan luonnollisen ja järjellisen lohkaisemista erilleen. Jos kuitenkin puhtaan järjen ajatellaan ilmaisevan itseään vain negatiivisesti, tämä alkaisi purkaa oppositiota. Eikö tässä piile sellainen käsitteellinen horjunta, joka ei pysy vastakohtien rajoissa? Kun Kant alkaa puhua moraalisesta valinnasta ja sen "edellyttämästä" radikaalista pahasta, hän tulee erottelun saumakohtaan, jota voi kuvata Nevanlinnan ja hänen kumppaneidensa termein. Tässä saumakohdassa joudutaan myös pohtimaan hämmentävää kysymystä "diabolisesta pahasta" eli pahasta omana moraalilakinaan. Žižek hyväksyy ajatuksen: jos kerran pahakin 
valitaan ajattomassa, transsendentaalisessa teossa, sekin on silloin puhtaan käytännöllisen järjen positiivisesti määrittyvä mahdollisuus. Jos taas Copjecin tavoin ajatellaan, että moraalilaki ilmenee vain traumaattisena paineena, siitä seuraa, ettei diabolisella pahalla voi olla positiivisesti määriteltävää sisältöä.

Nevanlinna erottaa Copjecia seuraten yliminän logiikan kantilaisesta imperatiivista. Yliminän logiikka - varsinainen moderni paha - vaatii nautinnon loputonta lykkäämistä ja uhraamista lopullisen palkinnon saamiseksi. Se tuottaa näin jatkuvan edistyksen fantasian, joka itse asiassa merkitsee elämän halveksuntaa. Lykkäävä fantasia myös peittää sen syyllisyyden, joka viestii toisenlaisen valinnan mahdollisuudesta. Se on kyltymätön, koska lopullista täyttymystä ei koskaan tule. Joka hetki tapahtuvan "viimeisen tuomion" perspektiivi sen sijaan vapauttaa tästä yliminän suuruudenhulluudesta. Kun tunnustetaan minän vieraantuminen itsestään, sen jakautuneisuus, tulee näkyviin mahdollisuutemme ja velvollisuutemme tehdä joka hetki valinta, joka ei palaudu ilmiömaailman ehtoihin ja sen tuottamiin fantasioihin. Koska meillä on tämä kyky, olemme enemmän kuin mitä teemme: olemme valitsevia subjekteja.

Kant avautuu moneksi. Vastakohtaisuuksien tasolla hän ilmentää liberalismin kaksijakoisuutta. Valinnan rajapinnasta ja subjektin itsevieraantumisesta käsin katsottuna hän tarjoaa mahdollisuuden ottaa eettistä etäisyyttä kiihtyvän funktionalismin maailmasta.

\section{Nietzsche ja pahan synty}

Hannu Sivenius tarkastelee nietzscheläistä pahan genealogiaa katsauksenomaisessa artikkelissaan "Pahan tällä puolen". Nietzschen näkökulmasta Kantin suorittamaa teodikean hylkäämistä ja metafysiikan kritiikkiä voi pitää vain osittaisena, koska tämä säilyttää omalla tavallaan absoluutin ja samalla ihmisen kahtiajaon vapauden (puhtaan järjen) ja kokemuksen maailmoihin. Tutkielmassaan Moraalin alkuperästä Nietzsche irtautuu metafysiikasta paljon radikaalimmin johtamalla hyvän ja pahan vastakohdan hyvän ja huonon suhteesta. Aristokratia oli asettanut "hyvän" suoraan omasta asemastaan, muu oli huonoa; hyvä ja paha syntyvät siitä käänteisesti orjakapinan kaunaisena reaktiona.

Sivenius osoittaa, kuinka Nietzsche "korvaa" kritiikin normien pohdinnan genealogian käsitteellään. Genealogian momentit ovat monumentaalihistoria (alhaisen ja pikkumaisen eettinen vastustaminen), antikvaarinen historia (kansan tai kansakunnan menneisyyden kunnioittaminen) ja kriittinen historia (menneisyyden satunnaisuuksien, väkivaltaisuuksien ja inhimillisten heikkouksien paljastaminen). Näitä kekseliäästi yhdistämällä historiantutkimuksen voi Nietzschen mukaan saattaa palvelemaan nykyisyyttä ja tulevaisuutta - "elämää". Filosofisesti tämä eri perspektiivien kokeilu merkitsee joko/tai -ajattelun ylittämistä. Sivenius korostaa, että Nietzscheä ei kannata lukea jonkin rationaalisen perustan etsimiseksi vaan moraalikäsityksiin iskostuneiden 
latteuksien paljastamiseksi. Hän ei herätä kysymystä Nietzschen oman moraalikäsityksen mahdollisesta latteudesta. Jos vaikkapa aristokratian "hyvä" määrittelee "terveen ylhäisesti" sosiaalisesti alempien huonouden eli alhaisuuden, voiko sen niin pidäkkeettömästi erottaa kriittisestä momentista? Mistä tulee tällainen myönteisyyden ja kielteisyyden kahtiajako?

Nietzschen käsittelyä jatkaa Miika Luoto kirjoituksessaan "Nietzschen hirvittävä ilosanoma”. Ilosanomassa hirvittää se, että ihmiseen juutalais-kristillisesti iskostetusta syyllisyydestä vapautuminen ja sen korvautuminen "tulemisen (Werden) viattomuudella" edellyttää kaikkien arvojen uudelleen arviointia - niiden perusteettomien perusteiden näyttämistä. Nietzschen immoralismi tarkoittaa moraalin kertakaikkista kyseenalaistamista siten, että osoitetaan kuinka moraalikäsitykset aina ovat kiinnittyneet vain tiettyyn elämänmuotoon. Luoto siteeraa: "moraali seurauksena, oireena, naamiona, Tartuffen-laatuna, sairautena, väärinymmärryksenä; mutta myös moraali syynä, parannuskeinona, kiihotusaineena, esteenä, myrkkynä”. Sen sijaan, että ajattelisimme moraalia lähtökohtana Kantin maksiimien tapaan, meidän tulee ajatella moraalia käytännön vaihtelevia tarkoituksia palvelevana - eräänlaisena siirtymin ja peittelyin toimivana uskomusten ja uskottelun retoriikkana.

Luoto jatkaa Siveniuksen aloittamaa käsittelyä herran ja orjan suhteesta, ja siitä hahmottuu selvemmin nietzscheläisen moraalin genealogian perusele. Nietzsche abstrahoi aristokratian elämänmuodosta nousevan "hyvän" kaiken syyllisyydentunnosta vapaan elämän myöntämisen periaatteeksi, kun taas alistettujen elämänmuodosta abstrahoituu elämää rajoittavan kaunaisuuden ja syyllisyydentunnon periaate. Orjalle herran suvereeni itsensä myöntäminen on paha, kaunan aihe - näin alistettujen elämänmuoto kääntää hyvän pahaksi.

Tämä on kovin ambivalentti ajatus, vaikka Luoto ja Sivenius eivät sitä sellaisena pohdi. Kysymys ei suoranaisesti ole yhteiskunnallisesta kannanotosta lyötyjen lyömiseksi, vaan pikemminkin yrityksestä osoittaa, kuinka sorron tosiasia kristinuskolla höystettynä tuottaa orjamoraalin rampauttavine syyllisyysobsessioineen. "Kriittinen momentti" kommentoi periaatteessa sortoa vääryytenä. Mistään yhteiskunnallisesta taistelusta Nietzschen katsannossa ei kuitenkaan ole kysymys, vaan halusta irtautua sidoksista "lapsen viattomuuteen", uuteen alkuun.

Mutta millä keinoin tässä on päästy hyvän ja pahan tuolle puolen? Jos alhaiset ovat ylhäisille huonoja (likaisia ja haisevia), eikö siihen sisälly moraalista latausta? Nietzsche esittää hyvän kääntymisen pahaksi yksinomaan alhaison kaunaisena reaktiona, mutta eikö tämä paha jo sisälly huonoon (lue: väheksyntään), toisin kuin Nietzschen "transsendentaalinen" erottelu antaa ymmärtää? Ja kun lika näin on tarttunut, mahtaako dionyysinen pyykkäys riittää sen puhdistamiseen uuden alun merkiksi? "Huonoon" sisältyvästä pahasta kiinni pitäminen siirtäisi pahan 
ensi sijassa ylhäisön toimien ja asenteiden vaikutukseksi. Nietzsche pääsee "huonon" moraalisesta latauksesta hyvän ja pahan tuolle puolen vain halkaisemalla ambivalenssin. Torjunta tuottaa yli-ihmisen, ja samassa heilahduksessa Zarathustran ajatus käskijää etsivästä yhteiskunnasta sysää syrjään äskeisen hyväntahtoisesti abstrahoivan kuvauksen vallantahdon luonteesta ja vaikutuksista.

\section{Lopuksi}

Kun Kant lähtee moraalilain kunnioittamisesta, Nietzsche tahtoo osoittaa naturalistisesti tällaisten asenteiden kiinnittymisen maailmallisiin käytäntöihin ja etenee pidäkkeettömään itsensä toteuttamiseen, affirmaatioon. Nietzsche on tullut uuteen keskusteluun tämän "myöntämisen" ja moraalin vakiintuneiden perusteiden purkamisen kautta; myös Foucault'n genealogia on vienyt katseet häneen, samoin kielen figuraalisuuden korostaminen. Kantin kautta taas on avautunut uudella tavalla ajankohtaistunut pahan problematiikka, usein lacanilaisesta psykoanalyysista kiinnostuneiden tutkijoiden vaikutuksesta, kuten myös Radikaali paha -kirjassa. Kun lisäksi tulevat pahan dekonstruktio, "banaalin" pahan pohdinta, kansainvälisen oikeuden kysymysten käsittely ja historiallinen analyysi natsioikeuden tavasta hyödyntää valistuksesta ja kantilaisuudesta juontuvaa oikeuspositivismia, on tuloksena tärkeä, moniulotteinen ja keskusteluun haastava kirja.

Erkki Vainikkala 


\section{Puhutteko jälkikolonialismia?}

Pirjo Ahokas \& Lotta Kähkönen (toim.) 2003 Vieraaseen kotiin. Kulttuurinen identiteetti ja muuttoliike kirjallisuudessa. Turun yliopisto. Taiteiden tutkimuksen laitos. Sarja A, n:o 52.308 s.

Jälkikoloniaalinen kirjallisuudentutkimus on suurimmaksi osaksi englanninkielistä. Sen tutkimuskohteena ovat puolestaan ne kirjalliset traditiot, jotka ovat olleet olemassa siirtomaavallan aikana, syntyneet sen kuluessa tai ottavat kantaa siirtolaisuuden ja imperialististen valtaasetelmien kokemuksiin. Kolonialistinen menneisyys on parin vuosikymmenen ajan saanut tutkijat kirjoittamaan ja merkityksellistämään historiaa uudelleen.

Viime vuonna ilmestynyt, Pirjo Ahokkaan ja Lotta Kähkösen toimittama Vieraaseen kotiin siirtää teoreettista painopistettä nykyaikaa kohti. Kirjan nimessä ja sen 11 artikkelissa nousevat keskeisiksi sekä ne olosuhteet, joissa ollaan, että ne, joihin saavutaan. Turun yliopiston yleisen kirjallisuustieteen tutkimusryhmä tuo näkyväksi kirjallisuusteorian nykykäsitteitä ja itse kirjallisuuteen vaikuttavia kiihtyvän kansainvälisen muuttoliikkeen seurauksia. Yhdysvaltain, Karibian ja Euroopan kirjallisuuksien tutkijat kysyvät: millaisia ovat ne identiteetit ja mahdolli- suudet, joita nykykirjallisuus tarjoaa?

Feministinen, jälkistrukturalistinen ja postkoloniaalinen tutkimus yhdistää toisiinsa kokoelman teoreettisesti polveilevia artikkeleita. Erityisesti painotetaan näkökulmia, joissa huomioidaan globaalin ja paikallisen, siirtolaisuuden, rodun, etnisyyden ja sukupuolen mutkikkaat suhteet. Kirjan kokonaisuuden kannalta tämä moniaineksisuus aiheuttaa jonkin verran toistoa ja hajanaisuutta. Silti teoksen vahvuus on nimenomaan teoriassa. Moniaalle versova kokonaisesitys on kattava ja perusteellinen johdatus: se antaa välineistöä nykytilan pohtimiselle. Suomenkielinen ja pääosin suomalaisten tutkijoiden kirjoittama teos avaa merkityksellistä ja ajankohtaista keskustelua kulttuurisidonnaisesta kirjallisuudesta ja tieteen tekemisen perinteestä. Teos herättää odotuksia siitä, mitä suomalainen teoretisointi voi tuoda angloamerikkalaiseen valtavirtaan hyväksyttyjen lähtökohtiensa rinnalle ja jatkoksi. 
yläluokkaisen englantilaismiehen aviovaimoksi.

Vieraaseen kotiin -teoksen välittämäs-

Matka kyseenalaistamattomissa olesä kirjallisuuskäsityksessä korostuu sekä kaunokirjallisuuden että tutkimuskirjoittamisen maailmallisuus. Kirjoittamisen tilanne on olla likainen ja epäpuhdas, poliittisesti ja eettisesti sitoutunut. Tutkijat purkavat auki ja solmivat uudelleen fiktiivisen kirjallisuuden sidosta suhteessa kirjoittamisajankohdan yhteiskunnallispoliittiseen liikehdintään. Kirjallisuudentutkimuksen kannalta voi olla vieläkin tärkeämpää, että kirjallisuus itse näyttäytyy paitsi tutkimuskohteena myös tutkimusmenetelmänä, jolloin kulttuurisia arvoja ja ideologioita ei pidetä kirjallisuuden ulkopuolisina rakenteina. Subjektiksi kasvamisen ja politisoitumisen yhteyttä korostava Giovanna Covi kirjoittaa: ”Nykyinen länsimaiseen episteemiin kohdistuva purkamisprosessi on todellakin uusi kopernikaaninen vallankumous, joka avaa meille täysin muuttuneen maailman" (2003, 162-163).

Teoksen karibialaisen osuuden aloittaa paikantamisen problematiikkaan keskittynyt Sara Eevan kirjoitus. Eeva tarkastelee kreolinaisen kulttuuri-identiteettiä Jean Rhysin romaanissa Wide Sargasso Sea (1964) ja hyödyntää muidenkin tutkijoiden käyttämää kulttuurisen hybridin käsitettä. Toinen tärkeä lähtökohta analyysille on Yhdysvalloissa opiskelleen Trinh Minh-han teoretisoima "Sopimaton Toinen". Käsitettä käytetään kreolinaisen, Rhysin kirjoittaman "valkoisen neekerin", vastarinnasta ja asettumisesta van, valkoisen kolonialistisen miehen mukana vie päähenkilö Antoinette / Berthan britti-imperiumin keskukseen. Hän joutuu paikkaan, joka on varattu kirjallisuushistorian sopimattomille, mielenvikaisille ja usein etnisille naisille. Vanhan kartanon ullakolle johtava matka saa toisen merkityksen kuin matka eurosentrisessä maailmankirjallisuudessa: "matka Englantiin on matka eristykseen ja tuhoon" (Eeva 2003, 120). Myös antigualaissyntyisen Jamaica Kincaidin tuotannossa syntyy Englannin todellisuus, jota kuvataan ensin välitilana. Tämä "leveä, syvä ja pimeä” tila on todellisuuden ja ajatuksen välillä. Dekolonisaatiota painottavan Giovanna Covin huomio koskee virkkeitä ja kiinnittyy jälkistrukturalismin teoriaan: se koskee sekä kieltä merkitysjärjestelmänä että todellisuutta symbolisen referenttinä. Kuvitellun, kielellisen ja todellisen muodostama epäjatkuva tai kompleksinen tila on Kincaidin tekstissä ilmaistu eloonjäämisen tapana, paikaltaan siirtymisenä. Rohkaisten ruumiillistuneeseen puhetapaan Giovanna Covi tulkitsee: "Virke (latinan sanasta sentire) on tunne; se on kohtaaminen, intohimo, identiteetti joka on olemassa hetken ja josta sitten tulee Lucyn tavoin "suuri hämäryys". Virke on Lucy..." (Covi 2003, 163.) Kincaidin esseen "Seeing England for the First Time" puhujaminän näkemät Doverin valkoiset kalliot, jotka vain näyttävät valkoisilta, merkityksellistyvät virkkeen 
tekemisen ja tuomion kautta (englannin sanasta sentence). Kuvitellut virkkeet rajoittavat tapahtumien ja todellisuuden merkityksiä (yhdeksi), antavat olemassaoloa määrittävät tuomiot. Kalliot, jotka merkityksellistyvät ristiriitaisesti valkoisina, viittaavat Kincaidin esseen puhujaminän kokemuksiin kreolina ja brittiläisyyden mustana merkitsijänä. Giovanna Covi tulkitsee edelleen "valkoisten kallioiden” merkitsevän ymmärrystä hylkäämisestä, toiveesta, että kaikki Englantia koskeva kuolisi, ja samalla ymmärrystä niin eloonjäämisen välttämättömyydestä kuin tarpeesta elvyttää voimia uutta lähtöä varten.

Jopi Nymanin artikkelissa saapumisen ja kotiinpaluun kyseenalaistaminen on toisen suuntaista. Mustasta Britanniasta Karibialle (ja takaisin) palaava $A$ State of Independence -romaanin päähenkilö on maskuliinisuudessaan kriisiytynyt siirtolainen, joka kotisaarelle palattuaan edustaa pikemmin englantilaistunutta natiivia intellektuellia kuin St. Kittsin alkuperäisväestöä. Jälkikolonialismin aiempaa paradigmaa kritisoiden Nyman osoittaa, että rotuun pohjautuva yhteisöllisyys on nostalginen fantasia, joka perustuu vanhentuneelle käsitykselle globalisaation tilanteesta. Fanonilainen vallankumousromantiikka epäonnistuu, sillä kansalliselle kulttuurille kasvavaa kollektiivista toimijuutta ei ainakaan Caryl Phillipsin romaanissa kohtaa (Nyman 2003, 215, 220)

Nymanin teesi on, että kansallisen identiteetin rapistuminen merkitsee paikkasidonnaisen kodin ja kodin käsitteen kyseenalaistumista. Selviytymisstrategiaksi hän tarjoaa Homi Bhabhan esittämää kolmannen tilan hyväksymistä. Siirtolaisen diasporinen identiteetti ei siten merkitse pysyvää kodittomuutta ja maanpakolaisuutta, vaan päähenkilön identiteetti määrittyy pikemminkin mustan brittiläisyyden vaikutusyhteydessä.

Vieraaseen kotiin -teoksen Yhdysvallatosassa tarkastellaan 1970-luvun kansalaisoikeustaistelujen jälkeistä aikaa, jolloin politisoitunut afrikkalaisamerikkalainen identiteetti tuli haastetuksi yhteisön sisältä. Ensimmäinen osa tarjoaa työkaluja eron ja erilaisuuden hyväksymiselle: se esittelee positiivisia mahdollisuuksia, heuristisia apuvälineitä ja strategioita, jotka osoittavat marginaaliin siirrettyjen ja vähemmistöidentiteetin onnistumisia. Pirjo Ahokas tuo nähtäville kenties kaikkein merkittävimmän mustan feministin ja kirjailijan Alice Walkerin ajattelua. Kulttuurihistoriallisesti tarkkanäköisesti Ahokas perustelee, kuinka Walkerin romaani Meridian (1976) teki tilaa mustien naisten poliittiselle olemassaololle ja heidän identiteettiensä heterogeenisyydelle. Ahokkaan löytö on mahdollisuus uuteen eettiseen diskurssiin. Omaa aikaansa edeltäen (myös) Alice Walker näki kumouksellista potentiaalia performatiivisessa subjektiudessa ja identiteetissä, joka muuttuu jatkuvasti.

Toinen voimakkaasti toivoa ylläpi- 
tävä rajojen ylittäjä on trickster-hahmo, paradoksaalisten mahdollisuuksien ruumiillistuma. Tony Morrisonin tuotantoon keskittynyt Kathleen Ashley perustelee selkeästi tricksterin arvon elävänä ja uusiutuvana kerronnallisena prosessina. "Trickster ei ole vain sosiaalisia rajoituksia ja alistamista vastustava hahmo, vaan se kuvaa myös sitä, miten ainoastaan ylittämällä nuo rajoitukset, jopa lempeätkin, muutos voidaan saada aikaan.” (Ashley 2003, 31.)

Säröttömäksi toimitetun kokoelman tutkijat tarttuvat myös seksuaalisen väkivallan ja sen uhan teemoihin. Rasismin ja patriarkaalisten diskurssien kyllästämässä maailmantilanteessa Minna Niemi ja Lotta Kähkönen keskustelevat kysymyksistä, jotka koskevat naisten ympärileikkausta ja valkoisen naisen konstituoimista maskuliinisen halun kohteeksi. Heidän eri reittejä seuraavat kirjoituksensa johtavat feministiseen ohjelmanjulistukseen. "Ainoastaan epäoikeudenmukaisuuden vastustaminen on pysyvä lähtökohta ilolle”, tiivistää Minna Niemi (2003, 75). Artikkelien radikaalisti todellisuutta mullistava havainto koskettaa "oikean naiseuden kulttia". Kun nykytilanteessa sukupuoliero on rodullistettu, seksualisoitu ja luokkaan kiinnitetty, valtakulttuuria on tarpeen lukea sekä vasta- että myötäkarvaan. Uusi eettinen diskurssi ja naisten keskinäinen solidaarisuus voivat syntyä käytännössä. Se vahvistuu heteroseksismin vastustamisesta ja kaikkien naisten oikeuksien arvostamisesta.
Vieraaseen kotiin -teoksen ensimmäinen osa päättyy valkoisuuden kriisiin. Toisessa osassa osoittautuu, että kolmannella maailmalla ja siirtolaisilla on oma, valkoiseen rasismiin liittyvä mutta myös siitä irrallinen problematiikkansa. Vaikka Franz Fanonin, Homi K. Bhabhan ja Stuart Hallin kaltaiset teoreetikot ovat raivanneet tilansa näissäkin akateemisissa lähdeluetteloissa, heidän ratkaisunsa eivät yksiselitteisesti auta sen paremmin mustia kuin valkoisiakaan.

Teoksen kolmas osa, Eurooppa, rakentuu kysymykselle mahdollisuudesta transkulttuuriseen elämännäkemykseen ja kerrontaan. Kolme artikkelia käsittelee kulttuurien synkretisoitumisen kysymystä ranskalaisen, saksalaisen, suomalaisen, arabi- ja afrikkalaiskulttuurien konfliktipisteissä. Päivi Mäkirinnan ja Marja-Leena Hakkaraisen kirjoitukset purkavat heikentyvän kansallisvaltion ja kansalaisuuden käsitteitä ja avaavat vaihtoehtoa identifioitua uuteen aikaan työstämällä rodun, sukupuolen ja yhteiskuntaluokan kategorioita. Heidän mukaansa "muistinmenetykset", jotka heikentävät kulttuurista identiteettiä, kuvaavat sekä eurooppalaista historiankirjoitusta että esimerkiksi karibialaista naiskirjallisuutta (ks. myös Ilmonen 2003).

Teoksen ainoa suomalaisuuteen palaava artikkeli liikkuu ohi symbolisen tason. Eila Rantosen "Nais-Eurooppa, nais-Afrikka ja jälkikoloniaalinen tilanne Veronica Pimenoffin romaanissa Maa il- 
man vettä" velvoittaa ottamaan poliittisen vakavasti. Rantonen haastaa lukijansa arvioimaan kirjallisuuden ja kirjallisuudentutkimuksen merkitystä ideologiakriittisesti ja suhteessa maailman tilanteeseen. Hänen mukaansa kolonialismin ja patriarkalismin vaikutukset ulottuvat sekä länteen että Afrikkaan, Latinalaiseen Amerikkaan ja Aasiaan; ne vaikuttavat kaikkien maailmankatsomuksiin, vaikka $\mathrm{mm}$. suomalaista kirjallisuutta ei voikaan yksinkertaisesti liittää postkoloniaaliin kirjallisuuteen.

Poliittisena eleenään Rantonen keskittää uudelleen tapaamme tarkastella todellisuutta. Liukuvat ja liikkuvat toiset eivät niinkään ole jotakin kysymyksen alaiseksi asetettavaa kuin on se fiktiivinen raja, jonka takana piilottelee kiinteä ja yhtenäinen subjekti. Kansa, kansallisuus ja koti ovat kuvitteellisia, kulttuurisidonnaisia muodostelmia. Kuuluminen johonkin on sen sijaan syvästi ihmisyyttä koskettava kysymys.

Vieraaseen kotiin tuo suomenkieliseen kontekstiin uutta karibialaisen kirjallisuuden aineistoa ja ennen kaikkea angloamerikkalaisen yliopistolaitoksen piirissä tuotettua teoriaa. Kielellinen rajanylitys on mielestäni tärkeä. Toinen merkittävä ansio on yritys ylittää imperialistinen projekti: lähtökohdiltaan eettinen ja poliittinen pyrkimys jäljittää nykyaikaista monikulttuurista kokemusta Yhdysvalloissa, Karibialla ja Euroopassa. Tämän seurauksena historiallinen tiedon intressi - paitsi tutkijan, myös lukijan kiinnostus - kohdistuu uudelleen, kategorioiden ja historian välitiloihin. Vielä nähtäväksi jää, minne "ylipaikallisuuteen" kurotteleva teoria yltää globalisaation paikallistamisen kysymyksissä, sen rotu- ja sukupuolivaikutusten arvioinnissa ja millaisia kysymyksenasetteluja kirjallisuudentutkijoille esitetään paikallisista käytännöistä.

\section{Sanna Kallioinen}




\section{Väitöskirjat}

\section{Syntipukkeja ja mustia kristuksia}

Tuire Valkeakari: Sacred Words and Secular Visions in Recent African-American Novels. Helsinki University Printing House, 2004. 348 s.

Tuire Valkeakarin väitöskirja on tervetullut lisä suomalaiseen kirjallisuudentutkimukseen, sillä afrikkalaisamerikkalainen fiktio näyttää kiinnostavan niin nuoria kirjallisuudentutkijoita kuin monia opiskelijoitakin. Teoksen laaja tutkimusmateriaali sisältää lähinnä kahdeksan mustan amerikkalaiskirjailijan romaanituotantoa viime vuosituhannen jälkipuoliskolta. Otsakkeen mukaisesti väitöskirjassa tarkastellaan "pyhän" kielen hyödyntämistä ja mukailemista maallisiin ja jossakin määrin myös uudelleen määriteltyihin hengellisiin tarkoituksiin. Tällöin uskonnollinen retoriikkaa ja troopit liitetään mustien amerikkalaisten identiteeteistään käymään neuvotteluun. Nykyistä afrikkalaisamerikkalaista kirjallisuudentutkimusta luonnehtii kulttuurintutkimuksellinen ote, ja prologissaan kirjoittaja kytkee tutkielmansa tähän valtavirtaan.

Sotienjälkeisen amerikkalaiskaanonin rakentajat näkivät mielellään Yhdysvaltain kirjallisuuden raamatullisessa valossa ja katsoivat valtakulttuurin kirjallisuuden ammentavan uuden Eedenin paratiisin kuvitelmista ja testaavan niitä. Raamatun perinne on leimannut kauttaaltaan myös pitkään marginaalistettua afrikkalaisamerikkalaista kirjallisuutta. Valkeakarin väitöskirjan johdantoluku onkin historiallinen katsaus hänen käsittelemäänsä ajanjaksoa edeltävään afrikkalaisamerikkalaiseen kirjallisuuteen. Kirjoittaja toteaa Katherine Clay Bassardiin tukeutuen, että kristinuskoon tulo antoi orjuutetuille mahdollisuuden rakentaa uudelleen musta subjektius. Jo spirituaalit ja mustien saarnat paljastivat kristinuskon kaksinaisuuden: yhtäältä uskonnollisella kielenkäytöllä voitiin oikeuttaa orjuus, mutta toisaalta se tarjosi myös vastarinnan mahdollisuuden. Useimmille lukijoille lieneekin tuttu Frederick Douglassin huomio, että orjat lisäsivät usein virsiin ja hengellisiin lauluihin maallisen merkityskerrostuman, joka viittasi orjuudesta vapautumisen poliittiseen tähdellisyyteen. 
Valkeakari kartoittaa perinnettä edelleen 1890-luvun lopulta aina Ralph Ellisonin romaaniin Invisible Man (1952), joka on ensimmäinen hänen varsinaisesti analysoimistaan teoksista.

Sinänsä on kiinnostavaa lukea, miten esimerkiksi sellaiset tunnetut mustat kirjailijat kuin James Weldon Johnson, Zora Neale Hurston, Langston Hughes, Jean Toomer tai Nella Larsen kehittelivät väitöskirjassa tarkasteltavaa traditiota. Pian alkaa kuitenkin toivoa, että kohdeteksteihin päästäisiin käsiksi hieman ripeämmin. Jäsennyksellisesti johdannon ja sitä edeltävän prologin erottaminen toisistaan tuntuu tarpeettomalta, sillä sellaiset perinteisesti johdantoon kuuluvat asiat kuten tehtävänasettelu ja työssä käytettävä teoriapohja otetaan esiin jo prologissa. Ratkaisuun lieneekin vaikuttanut se, että yhdistettyinä jaksot olisivat lohkaisseet huomattavan osan työn sivumäärästä.

Valkeakari täsmentää monitieteisten lähtökohtiensa olevan mustan kansankielen ja performatiivisuuden tutkimuksessa, musiikkitieteessä ja uskontohistoriassa (s. 16), mutta hän tähdentää myös Henry Louis Gatesin mustan kirjallisuuden intertekstuaalisuutta koskevan teorian suurta merkitystä koko tutkimusalalle. Ellisonin kohdalla kirjoittaja nostaakin musiikillisten ainesten käytön rinnalle Gatesin avainkäsitteen Signifyin(g). Se vertautuu jazzin ja bluesin improvisaatiotekniikkoihin, sillä Gates näkee afrikkalaisamerikkalaisen kirjallisuuden epäsuorasti toistavan tai muotoilevan uudelleen jotakin ennestään tunnettua mustaa tai valkoista lähdettä. Tällöin on usein kyseessä epäsuora parodinen tai ironinen vihjailu, suostuttelu tai kielellinen leikittely. Valkeakari argumentoi hyvin tehdessään lukijalle ihailtavan selväksi, miten hänen oma panoksensa eroaa hänen käyttämästään tutkimuskirjallisuudesta. Kun aikaisempi tutkimus on pitänyt mallinaan James Baldwinin tuotantoa, kirjoittaja väittää Ellisonin tyylillisesti uutta luovan romaanin toimineen modernistisena kimmokkeena hänen seuraajiensa estottomalle ja monitasoiselle uskonnollisen diskurssin hyödyntämiselle.

Väitöskirjan lukuja yhdistävät toisiinsa Ellisonin humoristisesti subversiivisen messiaanisen ja syntipukkidiskurssin hyödyntäminen sekä näiden diskurssien kytkeminen mustien kokemaan epäoikeudenmukaisuuteen ja rasistiseen syrjintään. Sujuva lähteiden kanssa keskustelu pääsee ehkä parhaiten oikeuksiinsa Ellisonia ja Morrisonin The Bluest Eye -teosta käsittelevissä osioissa. Valkeakari pitää Morrisonin romaanin päähenkilöä Pecolaa mustan yhteisön julmuuden kohteeksi joutuvana syntipukkina ja käänteisenä Kristus-hahmona. Analyysien kiinnostavuutta lisää se, että lähdeaineistonsa hallitsevalla Valkeakarilla on tarpeellinen taito lukea myös sisäistetyn rasismin ilmentymiä. Tämä näkyy varsinkin The Bluest Eye -romaanin omintakeisesta ja perusteellisesta luennasta.

Kolmanneksi tarkasteltavan kirjailijan, Leon Forrestin, kokeelliset teokset ovat jääneet sekä lukijamääriltään että tutkijoiden keskuudessa paljon vähemmälle 
huomiolle. Tämä luonnollisesti jättää runsaammin tilaa tutkijan omille väitteille ja tulkinnoille. Yleisesti ottaen Valkeakari katsoo performatiivisten piirteiden liittävän Ellisonin, Morrisonin ja Forrestin teoksia toisiinsa. "Performatiivisuus" ja "performanssi” sekä sellaiset käsitteet kuin "performatiivinen eetos" esiintyvät jo väitöskirjan alkuosassa, mutta varsinaiseen terminologiseen selvitykseen ryhdytään vasta Forrestin teoksiin tultaessa väitöskirjan puolivälissä. Valkeakarin teoreettisina innoittajina ovat ennen kaikkea Joseph Roach ja Kimberly B. Benston, jonka teosta Performing Blackness hän testaa Forrestin Witherspoon-Bloodworth -trilogiaa käsittelevässä luvussa. Forrestin trilogiassa mustien lynkkaukset vertautuvat Jeesuksen ristiinnaulitsemiseen, ja kirjoittaja soveltaa performanssiajatusta juuri näiden julmien kansankokousten esityksellistämiseen. Lisäksi hän osoittaa, että lynkkauksiin liittyvään kristilliseen ylösnousemuskertomukseen sisältyy myös afrikanistisia aineksia.

Mustan tutkimuksen painotus näyttäisi olevan nimenomaisesti performanssi-käsitteessä. Toisaalta taas jo kauan kulttuurin- ja kirjallisuudentutkimuksen keskiössä ollut performatiivisuus-käsite yhdistyy nykyisin liki automaattisesti Judith Butlerin sukupuolen esittämistä koskeviin teorioihin. Vaikka Butlerin performatiivisuuteen ei väitöskirjassa viitatakaan, tässä olisi silti toivonut terminologista rajankäyntiä. Korostaahan Gateskin myös länsimaisen, valkoisen teorian tuntemusta. Ajatukselta ei välty varsinkaan siksi, että kirjoittaja puhuu performanssin yhteydessä mustien identiteettien muotoutumisesta. Väitöskirjan kahdessa viimeisessä luvussa hän lisäksi nostaa identiteetin osatekijöistä sosiaalisen sukupuolen työtään strukturoivaksi pääperiaatteeksi ("a major structuring principle" s. 170). Tuolloin tutkimuskohteena ovat mustien miessaarnaajien ja naispuolisten hengellisten johtajien representaatiot.

Painotuksen siirtyminen sukupuoleen työn tässä vaiheessa ei voi olla oudostuttamatta, sillä musta feministinen kirjallisuudentutkimus nosti jo varhain näkyviin mustien naisten kokeman moninkertaisen sorron sekä korosti alistusjärjestelmien limittäisyyttä. "Rotu”, sukupuoli ja niihin liittyvä luokka-asema ovat olleet tasa-arvoisia muuttujia myös mustan maskuliinisuuden tutkimuksessa. Valkeakari perustelee ratkaisuaan kytkemällä valitsemansa teokset mustien hengellisessä yhteisössä käytyyn naispappeusdebattiin ja siten sukupuoliroolikeskusteluun. Mieskirjailijoiden mieskuvaa käsittelevässä luvussa hän analysoi miespuolisia saarnaajahahmoja Ernest Gainesin, Randall Kenanin ja John Edgar Widemanin romaaneissa. Naisten kuvaukset on puolestaan poimittu mustien naiskirjailijoiden teoksista. Esimerkiksi Kenanin Visitation-romaanin erittelyssä olisi päästy syvemmälle hyödyntämällä mustan homoseksuaalisuuden tutkimusta kahta Kenania koskevaa artikkelia laajemmin.

Miessaarnaajien hahmot on inhimillistetty paljastamalla heidän haavoittu- 
vuutensa ja erehtyväisyytensä, kun taas autonominen subjektius osoittautuu ensiarvoisen tärkeäksi Toni Morrisonin, Gayl Jonesin ja Octavia Butlerin luomille naissaarnaajille. Kirjoittaja toteaakin, että tutkittavien romaanien hengelliset naisjohtajahahmot tekevän kunniaa pitkään unohdetuille mustille naisedeltäjilleen. Naishahmojen analyyseissa korostetaan ruumiillisuutta ja keskitytään pelastusproblematiikkaan. Valkeakari pitää koko ajan historiallisena kontekstina Yhdysvaltoihin tuotujen mustien kärsimyshistoriaa. Jo aikaisempi luku osoitti Morrison-tutkimuksen runsauden. Valkeakari painottaakin keskittyvänsä Beloved-romaanissa vähemmälle huomiolle jääneeseen Baby Suggsin hahmoon. Orjien julma ja epäinhimillinen kohtelu on hyvässä tiedossa, mutta lukijaa vähintäänkin säpsähdyttää Beloved-analyysin osa, jossa pohditaan sitä, miten orjien rautakuolaimet vaikuttivat mustaan identiteettiin.

Valittuja romaaneja luonnehtii huoli mustien identiteeteistä, yhteisöstä ja tulevaisuudesta. Tulkinnoissaan Valkeakari onnistuu osoittamaan, miten hänen tarkastelemansa teokset hyödyntävät uskonnollisen diskurssin ja usein myös mustan musiikin eri muotoja. Aika ajoin kirjoittajan "temaattisiksi yhteenvedoiksi" kutsumat jaksot katkaisevat lupaavasti alkaneen argumentoinnin ja vievät tilaa tekstianalyyseilta. Väitöskirjan puolitiehen jäävä lopetus on omiaan tehostamaan hajanaisuuden vaikutelmaa. Katsaus tutkielman muodolliseen puoleen osoittaa sen olevan erittäin huolellisesti laadittu.
Haittana pidän kuitenkin tieteellisessä työssä tarpeellisten henkilö- ja asiahakemistojen puuttumista.

Kokonaisuudessaan Valkeakarin väitöskirja on vaatinut suuritöisen esivalmistelun. Kirjoittaja hallitsee suvereenisti uskonnollisen diskurssin ja laajan tutkimuskirjallisuutensa. Intertekstuaalisen suhteiden jäljittäminen ei ainoastaan paljasta, että hän on perehtynyt erinomaisesti mustaan kirjallisuuteen ja kulttuuriin, vaan se on alan muille tutkijoille sekä antoisaa että informatiivista. Englanninkielisen teoksen toivoo löytävän myös kansainvälisen lukijakunnan.

\section{Pirjo Ahokas}




\section{Hyötyykö feministi homosaunoissa viihtyneestä filosofista?}

Anita Seppä: The Aesthetic Subject. Exploring the Usefulness of Foucauldian tools in Feminism. http://ethesis.helsinki.fi, Helsingin yliopisto, Helsinki, 2003. 254 s.

Anita Sepän väitöskirja on todellinen pioneerityö, koska se on maassamme ensimmäinen estetiikan väitöskirja, joka keskittyy nimenomaan feministisen estetiikan kysymyksiin. Foucault'n etiikkaa, elämänkäytäntöjen filosofiaa, ei feminismin ja estetiikan näkökulmista ole maailmallakaan liikoja tutkittu. Väitöskirjassaan Seppä testaa Michel Foucault'n teoreettisten linjausten mahdollisuuksia feministisen teorian ja estetiikan kehittämisessä. Hän lähtee tulkinnassaan siitä, että Foucault'n tuotantoa yhdistää kiinnostus subjektin problematiikkaan ja vaikka ranskalaisajattelija käytti eri tuotantonsa vaiheissa eri matriiseja vallan ja subjektiuden kytkösten analyysissään, hänen tuotantoaan sopii luonnehtimaan pikemmin jatkumo kuin jyrkät katkokset. Seppää, joka kiinnittää katseensa nimenomaan esteettisen rooliin Foucault'n ajattelussa, kiinnostaa erityisesti tämän filosofian kolmas vaihe, eettinen käänne.

Etiikka ja estetiikka saavat erityisaseman Foucault'n ajattelussa hänen kah- dessa viimeisessä teoksessaan, antiikin hyvän elämän ja elämäntaidon minätekniikoihin keskittyvissä tutkimuksissa Nautintojen käyttö (L'Usage des plaisirs) ja Huoli itsestä (Le Souci de soi). Kreikkalaista ja roomalaista mieseliitin elämäntaitoa käsittelevät teokset ilmestyivät vuonna 1984. Tutkimukset tyrmistyttivät ne, jotka odottivat jatkoa Seksuaalisuuden historian ensimmäiselle osalle. Antiikintutkijahan aatehistorioitsija Foucault ei ollut. Siksi hänen kontribuutionsa on herättänyt intensiivistä kädenvääntöä niin antiikintutkijoiden kuin filosofienkin keskuudessa. Foucault'n tuotannon kiistellyin osa on nimenomaan myöhäiskausi, joka tarjoaa Sepällekin tutkimustyön keskeiset tulkinnan avaimet.

Foucault'n eettis-esteettisen ajattelun osalta Sepän korpus on pitkälti yhtenevä David M. Halperinin ylittämättömän Foucault-eksegeesin Saint Foucault. Towards a Gay Hagiography (1995) kanssa. Molemmat tarkastelevat Foucault'n myöhäistuotannon ja hänen julkaistujen 
haastatteluiden pohjalta sitä, miten tämä tulkitsi radikaalisti uudella tavalla antiikin ajatuksia elämisen taidosta tai elämästä taideteoksena (kreikkalaisten tekhnç tou biou). Sepän väitöskirjassa urakka on toki isompi. Hänen hankkeensa painopiste poikkeaa Foucault'n ja queer-politiikan suhdetta tutkailevan Halperinin vastaavasta.

Seppä etsii esteettisiä tematisointeja Foucault'n koko tuotannosta. Lisäksi hänen projektinsa liittyy feministisen filosofian projektiin sekä siihen, miten Foucault'n tuotannosta, nimenomaan hänen eettisestä ja esteettisestä ajattelustaan, löytyy välineitä feministisen filosofian kehittelyyn radikaalin pluralismin ja postfeministisen moniäänisyyden suuntaan. Työnsä lopussa hän pyrkii solmimaan yhteen viime vuosikymmenien keskustelua ruumiillisuudesta, sukupuolinormien horjuttamisesta nykytaiteessa, dragista ja performatiivisuudesta. Pakollinen Butler-annos esitetään lopussa ikään kuin myöhästyneenä Gender Trouble -referaattina sen sijaan, että rikasta postfeminististä keskustelua olisi hyödynnetty johdonmukaisesti kautta työn ja solmimalla postfeministinen argumentaatio kiinteäksi osaksi työn kokonaisuutta. Nyt työn huojahtelu eri feminististen näkökulmien välillä saa pohtimaan ohjauksen roolia väitöskirjan syntyprosessissa. Yleisesti ottaen tekijä on varmemmalla pohjalla pyrkiessään osoittamaan esteettisen periaatteen läpäisevyyden Foucault'n ajattelussa kuin selvitellessään feminismin subjektin suhdetta foucault'laiseen filosofian perinteeseen.
Väitöskirja jakautuu kolmeen pääjaksoon, joista ensimmäisessä Seppä keskittyy Foucault'n varhaistuotantoon. Siinä hän rinnastaa toisiinsa Foucault'n tiedon arkeologian ja avantgarden esteettiset periaatteet. Työn toisessa osassa hän selvittelee Foucault'n vallan analytiikan luonnehtimaa geneologista projektia. Juuri tämä biovallan ja diskursiivisen vallan käsitteillä operoiva Foucault on yleensä ollut feminististen lukutapojen kohteena. Teoksen kolmas osa keskittyy eettiseen käänteeseen, subjektin suhteeseen itseensä erilaisten minä-tekniikoiden näkökulmasta sekä Foucault'n ja postfeministisen ajattelun rinnastamiseen, jossa työn eri ainekset jäävät ongelmallisesti toisistaan irrallisiksi palasiksi.

On ilahduttavaa, että feministinen tutkimus vakiinnuttaa paikkaansa myös suomalaisessa filosofisessa estetiikassa, edelsihän tätä väitöskirjaakin suomalaista feminististä estetiikkaa monipuolisesti esittelevä artikkelikokoelma Kauneuden sukupuoli (2002), jonka toinen toimittaja Seppä oli. Tässä esittämäni kritiikki liittyy pitkälti siihen, että feministisen estetiikan kuten yleisemminkin feministisen teorian kentällä vallitsee jo nyt melkoinen näkökulmien moninaisuus. Sama moninaisuus, joka ajoittain yltyy ristivedoksikin, näkyy hyvin selvästi siirryttäessä keskustelemaan Foucault'n feministisistä lukutavoista. Seppä esittää monipuolisesti perustellen oman kantansa. Hän lähtee ajatuksesta, että Foucault'n merkitys feministiselle teorianmuodostukselle ja radikaaleille feministisille käytännöille on huomattava. Samalla hän suhtautuu 
tutkimuskohteeseensa kriittisesti sekä arvioi realistisesti niitä ongelmia, joita Foucault'n ajattelun mieskeskeisyys ja sukupuolisokeus tuottavat feministiselle teorialle.

Väitöskirja ei ole sivumäärältään tavattoman laaja, mutta siinä pyritään käsittelemään ehkä turhankin mahtavaa ongelmakenttää: yhtäältä selvitettävänä on estetiikan asema Foucault'n kokonaistuotannossa, toisaalta filosofin anti feminismille. Liian suuren palan haukkaamiseen liittyvät rajaamisen ja painotuksen ongelmat näkyvät siinä, että teos tarjoaa paljon kiinnostavaa pohdintaa liittyen Foucault'n esteettisen ajattelun painopisteisiin, mutta esimerkiksi ekskursiot Baudelaireen, dandyismiin ja jopa Sartren filosofiaan jäävät kytkeytymättä vakuuttavaksi kokonaisuudeksi. Erillisinä kokonaisuuksina niitä olisi kannattanut syventää, sillä Foucault'n esteettisessä ajattelussa riittäisi tutkittavaa. Toisaalta puhe eri feminismeistä, kauneusnormeista ja esteettisestä kirurgiasta jäävät myös päälle liimatuksi "feministiseksi problematiikaksi". Liian suuren asiakokonaisuuden mahduttaminen yhteen kirjaan näkyy myös siinä, että argumentaatiolle keskeiset käsitteet tulevat eksplikoiduiksi hyvin heikosti. Keihin esimerkiksi viitataan näennäisen ongelmattomasti puhuttaessa naisista, mikä tai ketkä oikein ovat teoksessa pohditun feministisen emansipaation subjekteja? Toinen vastaava ongelma on kautta työn toistuva epäselvä tapa luonnehtia feminismiä ja siitä (jollakin perusteella) erotettavaa postfeminismiä. Postfeminismistä on keskusteltu paljon - Seppä paljastaa oman feminismin ja postfeminismin erotteluperiaatteensa vasta työn loppuviitteissä. Sama käsitteenmäärittelyn ja oman työn kontekstoimisen ongelma toistuu esimerkiksi keskustelussa termeistä female, femini$n e$, feminist, tämäkin jää viitteen varaan. Muutoinkin lopun viiteapparaatti sisältää monia sellaisia asiakokonaisuuksia, joiden käsittely leipätekstissä olisi itse asiassa tuonut työlle luontevasti sellaisen ajatuksellisen rungon, joka olisi voinut kantaa rohkeampiin johtopäätöksiin kuin nyt valittu, missä Foucault kytketään melko lailla pakotetusti mm. Kantin kanssa valistuksen ja emansipaation "suuren kertomuksen” edistäjien joukkoon. Estetiikan subjektin, feministisen projektin subjektin ja Foucault'n koko tuotannosta hahmottuvan subjektiksi tulemisen projektin liittäminen yhteen osoittautuu huomattavan ongelmalliseksi hankkeeksi.

Työn ensimmäisessä jaksossa tekijä esittää myös katsauksen sukupuolieron feminismiin. Hänen mukaansa Foucault'n varhaistuotannon käsitykset subjektin esteettisestä muotoutumisesta on mielekästä rinnastaa Luce Irigarayn ja Hélène Cixous'n teorioihin; jokaista näistä esteettisistä käsityksistä voidaan luonnehtia avantgarden ja utooppisuuden yhdistelmäksi. Tässä muodossa Sepän argumentaatio ei kokonaisuudessaan vakuuta, vaikka luku tarjoaa kiinnostavia oivalluksia Foucault'n varhaisen ajattelun suhteesta esteettiseen. Irigarayn ja Cixous'n teorian esittely jää silti irralliseksi, eikä luvun loppuun liitetty kap- 
pale, jossa näiden ajattelua tarkastellaan kriittisesti, tuo helpotusta koko työn keskeiseen ongelmaan. Vaikka Seppä pyrkii sitomaan oman työnsä Jana Sawickin radikaalisti moniarvoiseen feminismiin ja Judith Butlerin postfeministiseen ajatteluun, se on samalla pinnanalaisesti tiukasti sidoksissa sukupuolieron feminismin käsitteistöön. Tämän vuoksi väitöskirjan käsitys feminismistä, sukupuolesta ja seksuaalisuudesta jähmettyy ongelmallisen konservatiiviseksi.

Englanninkielisessä väitöskirjassa pinnanalainen, työstämättä jäävä sidos sukupuolieron feminismiin näkyy esimerkiksi siinä, että teoksessa toistuva sex(ual) /sexual identity -termistö viittaa toistuvasti sen kummemmitta selityksittä - mihin? Seksuaalisuuden, sukupuolen ja identiteetin käsitteet ovat kautta teoksen ongelmallisella tavalla solmussa, vastaavalla tavalla jää työstämättä etiikan ja politiikan suhde. Seppä huomauttaa kohteliaasti sukupuolieron feministien saamasta kritiikistä, joka liittyy luokkaan ja rodullistaviin käytäntöihin, mutta hän vaikenee kokonaan näiden teorioiden heteroseksistisyydestä käydystä keskustelusta. Jälkimmäinen keskustelu kuitenkin avaisi huomattavan hedelmällisiä tarkastelukulmia yhtä lailla feminismin haasteisiin, Foucault'n sukupuolisokeuteen kuin tämän ajattelun radikaaliin queeriuteen, jonka pohjalta voisi kehitellä erittäin kiinnostavia rinnastuksia hegemonisia valta-asemia haastavan postfeministisen ajattelun suuntaviivoiksi. Tämä "halperinilainen" haaste väitöskirjassa valitettavasti ohitetaan kokonaan.
Ehkäpä juuri Halperinin työstämä puoli Foucault'n "myöhäistuotannosta" tarjoaisi feministiselle projektille toimivamman analogian lähtökohdaksi kuin se problematisoimaton ajatus naiseudesta, mihin Seppä työssään sitoutuu (ohittaen kokonaan Butlerin työn mahdollistaman postfeministisen projektin, jossa väitöskirjassakin hahmoteltu kysymyksenasettelu on ollut alusta läsnä saakka). Feminismin haaste Foucault'lle ei kenties olekaan siinä, että meidän tulisi vaatia naispuolisia esimerkkejä "hullun", "vangin" ja "homon" rinnalle. Kenties haaste ja mahdollisuus liittyvätkin tietämisen ja puheoikeuden radikaaliin positionaalisuuteen, jota Halperin Foucault'n pohjalta kehittelee. Tällöin naiseus ja samansukupuolisen rakkauden ja seksin "marginalisoivat" käytännöt voidaan tulkita esimerkeiksi "eksentrisestä positionaalisuudesta", subversiivisista tietämisen ja tutkimisen paikoista. Jos Foucault'ta luetaan "toiseuden" mahdollisuuksista ja toiseuttamisen käytännöistä kirjoittavana teoreetikkona, hänen antiaan feministiselle projektille voisi lähestyä hyvinkin eri näkökulmasta kuin nyt tarkastellussa hankkeessa. Väitöskirjassa luonnollistetun naiseuden jalkoihin jäävä foucault'lainen (miesten homokulttuuriin keskittyvä) eettinen projekti voisi sittenkin tarjota paradigman myös subversiivisen feministisen ajattelun työstämiselle, jossa toteutuisi feminismille ja etiikalle yhteinen toisin ajattelemisen haaste.

\section{Pia Livia Hekanaho}

